Article

\title{
The Fish Pathogen Vibrio ordalii Under Iron Deprivation Produces the Siderophore Piscibactin
}

\author{
Pamela Ruiz ${ }^{1,2}$, Miguel Balado ${ }^{3}$, Juan Carlos Fuentes-Monteverde ${ }^{4}\left(\mathbb{D}\right.$, Alicia E. Toranzo ${ }^{3}$, \\ Jaime Rodríguez ${ }^{4}$, Carlos Jiménez ${ }^{4}$ (D), Ruben Avendaño-Herrera ${ }^{1,2, *}$ \\ and Manuel L. Lemos ${ }^{3, *(D)}$ \\ 1 Laboratorio de Patología de Organismos Acuáticos y Biotecnología Acuícola, Facultad de Ciencias de la \\ Vida, Universidad Andrés Bello, 2531015 Viña del Mar, Chile \\ 2 Interdisciplinary Center for Aquaculture Research (INCAR), 2531015 Viña del Mar, Chile \\ 3 Departamento de Microbiología y Parasitología, CIBUS-Facultad de Biología and Instituto de Acuicultura, \\ Universidade de Santiago de Compostela, 15782 Santiago de Compostela, Spain \\ 4 Centro de Investigacións Científicas Avanzadas (CICA), Departamento de Química, Facultade de Ciencias, \\ Universidade da Coruña, 15071 A Coruña, Spain \\ * Correspondence: reavendano@yahoo.com (R.A.-H.); manuel.lemos@usc.es (M.L.L.)
}

Received: 31 July 2019; Accepted: 31 August 2019; Published: 3 September 2019

\begin{abstract}
Vibrio ordalii is the causative agent of vibriosis, mainly in salmonid fishes, and its virulence mechanisms are still not completely understood. In previous works we demonstrated that $V$. ordalii possess several iron uptake mechanisms based on heme utilization and siderophore production. The aim of the present work was to confirm the production and utilization of piscibactin as a siderophore by $V$. ordalii. Using genetic analysis, identification by peptide mass fingerprinting (PMF) of iron-regulated membrane proteins and chemical identification by LC-HRMS, we were able to clearly demonstrate that $V$. ordalii produces piscibactin under iron limitation. The synthesis and transport of this siderophore is encoded by a chromosomal gene cluster homologous to another one described in $V$. anguillarum, which also encodes the synthesis of piscibactin. Using $\beta$-galactosidase assays we were able to show that two potential promoters regulated by iron control the transcription of this gene cluster in V. ordalii. Moreover, biosynthetic and transport proteins corresponding to piscibactin synthesis and uptake could be identified in membrane fractions of $V$. ordalii cells grown under iron limitation. The synthesis of piscibactin was previously reported in other fish pathogens like Photobacterium damselae subsp. piscicida and V. anguillarum, which highlights the importance of this siderophore as a key virulence factor in Vibrionaceae bacteria infecting poikilothermic animals.
\end{abstract}

Keywords: Vibrio ordalii; fish pathogens; iron uptake; siderophores; piscibactin; vanchrobactin

\section{Introduction}

Vibrio ordalii is a $\gamma$-proteobacterium which causes vibriosis, a hemorrhagic septicemia, in several species of aquacultured fish, mainly salmonids [1]. Although vibriosis outbreaks due to V. ordalii have been reported around the globe, in the last 15 years they reached an important impact in Chile, where they cause significant economic losses in salmonids aquaculture [2,3]. Besides its genetic similarity to $V$. anguillarum [4,5], another important fish pathogen with worldwide distribution, many aspects of the virulence mechanisms of $V$. ordalii still remain unknown. While its pathogenicity is not correlated to erythrocytes hemagglutination capacity or biofilm formation in Atlantic salmon (Salmo salar), the hydrophobic properties of $V$. ordalii cells could play a role in virulence. Moreover, $V$. ordalii can evade the host immune system and can survive within Atlantic salmon mucus, which likely facilitates colonization $[3,6]$. However, many aspects of its ability to colonize and multiply within the fish hosts remain unclear. 
For most bacteria iron uptake ability during the naturally iron-limited conditions of an infection is a key virulence factor essential for multiplication within the host [7-9]. Besides the importance of iron for the cell metabolism, this element is an important signal that regulates expression of many other metabolic and virulence functions in bacterial cells [10]. This regulation is usually mediated by the transcriptional regulator Fur which needs $\mathrm{Fe}^{2+}$ as cofactor to bind to the promoter region of genes controlled by iron levels and prevent the binding of RNA polymerase to DNA [11]. The main mechanisms described in Gram-negative bacteria to get iron from the cell surroundings are the direct use of heme groups as a source of iron [12] and the synthesis of siderophores, which can efficiently sequester the iron bound by transferrins and other iron-holding proteins within the host $[9,13,14]$. The ferri-siderophore is then internalized through specific TonB-dependent outer membrane protein receptors that are energized through the TonB system [15-17]. Bacterial fish pathogens are not an exception for iron requirements and several mechanisms of iron uptake, including the use of heme and the synthesis of siderophores, have been reported in many of these bacteria [18-25].

We have previously demonstrated that $V$. ordalii can also use heme and hemoglobin as iron sources and that it has the ability to produce siderophores [26]. However, despite the clear relationship between $V$. ordalii iron uptake ability and pathogenicity, the precise nature of the iron assimilation mechanisms remains unclear. In this previous work, from genetic and genomic analysis, the results of cross-feeding assays, and from some other data in the literature [4], we suggested that $V$. ordalii could likely produce piscibactin as a siderophore. Piscibactin was isolated and characterized from the fish pathogen Photobacterium damselae subsp. piscicida [23]. In this bacterium piscibactin synthesis is encoded in a pathogenicity island harbored in the pPHDP70 virulence plasmid [27]. Recent in silico genomic studies in the Vibrionaceae family showed that the gene cluster encoding piscibactin synthesis and transport is really widespread in many species of Vibrio and Photobacterium [28]. In fact, we have recently demonstrated that some strains of $V$. anguillarum, a bacterium closely related to $V$. ordalii, produces piscibactin in a temperature-dependent fashion, being preferentially expressed at low temperatures. In these conditions piscibactin synthesis is a key virulence factor for V. anguillarum [29].

In the present work, we have characterized the gene cluster encoding the biosynthesis and transport of piscibactin and demonstrated, by genetic, proteomic and chemical analysis, that piscibactin is indeed produced as siderophore by $V$. ordalii.

\section{Materials and Methods}

\subsection{Bacterial Strains and Growth Conditions}

Three V. ordalii strains were used: The type strain ATCC $33509^{\mathrm{T}}$ and two strains, Vo-LM-13 and Vo-LM-18, previously isolated from vibriosis outbreaks in Atlantic salmon cultured in Chile [3,6]. All were confirmed as $V$. ordalii according to the PCR protocol previously described [30]. All strains were routinely cultivated on Trypticase Soy Agar or Trypticase Soy Broth supplemented with $1 \%$ (w/v) $\mathrm{NaCl}$ (TSA-1 and TSB-1, respectively). For some experiments the CM9 minimal medium was also used [31]. Stock cultures were kept frozen at $-80^{\circ} \mathrm{C}$ in Criobilles tubes (AES Laboratories, Combourg, France) or in TSB-1 with $15 \%$ (v/v) glycerol.

\subsection{RNA Extraction and RT-PCR}

To analyze the transcriptional regulation of the gene cluster involved in the biosynthesis and transport of the siderophore piscibactin, a RT-PCR was performed with the primers listed in Table 1. For this assay, $V$. ordalii Vo-LM-18 was grown in iron-limited (TSB-1 plus 2,2'-dipyridyl), iron-excess (TSB-1 plus $\mathrm{FeCl}_{3} 10 \mu \mathrm{M}$ ) and standard conditions (TSB-1). Total RNA was prepared from cultures after $48 \mathrm{~h}$ post-incubation using TRIzol ${ }^{\circledR}$ reagent (Ambion-ThermoFisher, Waltham, MS, USA) according to the manufacturer's instructions. Each RNA sample was subjected to treatment with DNase I RNase free. To obtain the cDNA, $5 \mu \mathrm{g}$ total RNA and reverse transcriptase enzyme M-MLV (Invitrogen-ThermoFisher, Waltham, MS, USA) was used following the manufacturer's instructions for each reverse transcription 
reaction. The PCR reaction was prepared with the cDNA, $1 \mathrm{U}$ of BioTaq DNA polymerase (Bioline, Memphis, TN, USA), $200 \mu \mathrm{M}$ of each dNTP and $2 \mathrm{mM} \mathrm{MgCl}_{2}$, final concentration. Depending on the melting temperature ( $\mathrm{Tm}$ ) of each pair of primers, annealing temperatures ranged from 55 to 60 ${ }^{\circ} \mathrm{C}$. Times of elongation were selected based on the expected size of amplification $\left(1 \mathrm{~min} \cdot \mathrm{kb}^{-1}\right)$. In all cases, the same reaction mixture, but without reverse transcriptase, was used as negative control, and chromosomal DNA of the Vo-LM-18 strain was used as positive control.

Table 1. Primers used in this work.

\begin{tabular}{|c|c|c|}
\hline Primers & Sequence $\left(5^{\prime}-3^{\prime}\right) *$ & d Fragment (bp) \\
\hline \multicolumn{3}{|c|}{ Amplification of potential promoters } \\
\hline P1 & & \\
\hline Promoter 1_F & GCGTCTAGACACTTTGCCACCCACCATTA & \multirow{2}{*}{879} \\
\hline Promoter 1_R & GCGGGATCCACGAATCGTCGTGTTGGCAT & \\
\hline \multicolumn{3}{|l|}{ P2 } \\
\hline Promoter 2_F & GCGTCTAGACCGCTTAGAGAAACCAACGT & \multirow{2}{*}{1165} \\
\hline Promoter 2_R & GCGGGATCCACGTTTCGGTAAGCGTATGG & \\
\hline & \multirow{3}{*}{\multicolumn{2}{|c|}{$\begin{array}{l}\text { Transcriptional regulation of irp gene cluster } \\
\text { TTTGGAGATGAGTGCGACAC }\end{array}$}} \\
\hline $\mathrm{RT}$ & & \\
\hline PCR1 & & \\
\hline ARC1ordalii_F & GATATGCGCTTTGACTGCCA & \multirow{2}{*}{196} \\
\hline ARC1ordalii_R & CTGTGAGACGGCATACAAGC & \\
\hline \multicolumn{3}{|l|}{ PCR2 } \\
\hline FrpA_ordalii_F & CGGTGGTAATGCTCAAGGTG & \multirow{2}{*}{204} \\
\hline FrpA_ordalii_R & TGGCTCGGTAGGTGTTCAAT & \\
\hline \multicolumn{3}{|l|}{ PCR3 } \\
\hline Irp2_ordalii_F & AGCAGGCAACAAAGAGTGAG & \multirow{2}{*}{413} \\
\hline Irp1_ordalii_R & GGGCGAATAACCAAACAAGC & \\
\hline
\end{tabular}

\subsection{Construction of lacZ Transcriptional Fusions and $\beta$-Galactosidase Assays}

The presence of potential gene promoters within the piscibactin gene cluster of $V$. ordalii was performed using BPROM tool [32]. Putative Fur boxes were detected by an in silico search of the GATAAT hexamer [33]. DNA fragments corresponding to V. ordalii frpA and araC1 promoter regions (P1 and P2, respectively) were amplified by PCR using primers specified in Table 1 . The amplified fragments included the region upstream of the start codon and the first nucleotides (ca. $50 \mathrm{bp}$ ) of frpA or $\operatorname{ara} \mathrm{C} 1$ coding sequences. These putative promoter regions were fused to a promoterless lac $\mathrm{Z}$ gene and inserted into the low-copy-number reporter plasmid pHRP309 [34]. The resulting transcriptional fusion constructs, P1::lacZ and P2::lacZ, were mobilized from Escherichia coli $\beta 3914$ into V. ordalii Vo-LM-18 by conjugation. Transformed ex-conjugants were selected on the basis on their resistance to gentamicin (pHRP309 marker). As a negative control, V. ordalii Vo-LM-18 with an empty pHRP309 was used. To determine whether potential promoters were regulated by iron, a total of four growth conditions were tested for each one of the transcriptional fusions: Cells grown in CM9, cells grown under iron excess (CM9 plus $\mathrm{FeCl}_{3} 20 \mu \mathrm{M}$ ) and two iron limiting conditions, CM9 plus 2,2'-dipyridyl $25 \mathrm{mM}$ and CM9 plus 2,2'-dipyridyl $80 \mu \mathrm{M}$. All cultures were carried out with agitation at $100 \mathrm{rpm}$ at $18^{\circ} \mathrm{C}$ until an $\mathrm{OD}_{600} \sim 0.1$ to record the $\beta$-galactosidase activity.

The transcriptional activity was determined by measuring the $\beta$-galactosidase activity of fusions $P 1::$ lacZ and P2::lacZ following the method described by Miller [35]. Volumes of 0.1 and $0.5 \mathrm{~mL}$, respectively, were used. Both were brought to a final volume of $1 \mathrm{~mL}$ with buffer $\mathrm{Z}\left(\mathrm{Na}_{2} \mathrm{HPO}_{4} 2 \mathrm{H}_{2} \mathrm{O}\right.$ 
$60 \mathrm{mM} ; \mathrm{NaH}_{2} \mathrm{PO}_{4} \cdot \mathrm{H}_{2} \mathrm{O} 40 \mathrm{mM} ; \mathrm{KCl} 10 \mathrm{mM} ; \mathrm{MgSO}_{4} 7 \mathrm{H}_{2} \mathrm{O} 1 \mathrm{mM}$ and $\beta$-mercaptoethanol $50 \mathrm{mM}$; $\mathrm{pH}$ 7.0). To this mixture $20 \mu \mathrm{L}$ of chloroform and $10 \mu \mathrm{L}$ of a solution of $0.1 \%$ SDS were added and the final solution was incubated at $37^{\circ} \mathrm{C}$ for $5 \mathrm{~min}$. The reaction was initiated by adding $0.2 \mathrm{~mL}$ of ortho-nitrophenyl- $\beta$-galactoside (ONPG; $4 \mathrm{mg} \cdot \mathrm{mL}^{-1}$ in $\mathrm{Z}$ buffer). The reaction was stopped with $0.5 \mathrm{~mL}$ of $1 \mathrm{M} \mathrm{Na}_{2} \mathrm{CO}_{3}$ when a color change to yellow was generated. Finally, $\mathrm{A}_{420}$ was measured in a UV-VIS spectrophotometer (Hitachi U2000, Tokyo, Japan).

\subsection{Analysis of Outer Membrane Proteins (OMP) Profile of V. ordalii}

OMPs were obtained from V. ordalii strains ATCC $33509^{\mathrm{T}}$, Vo-LM-18, and Vo-LM-13 grown under iron excess (TSB-1) and iron limitation (TSB-1 + 2,2'-dipyridyl, using a concentration half of the specific MIC for each strain). Each strain was cultured in $500 \mathrm{~mL}$ of TSB-1 or TSB- $1+2,2^{\prime}$-dipyridyl at $18^{\circ} \mathrm{C}$ for $48 \mathrm{~h}$. After incubation, the media were centrifuged at $10,000 \times \mathrm{g}$ for $10 \mathrm{~min}$ at $4{ }^{\circ} \mathrm{C}$. The cell pellets were resuspended in $3 \mathrm{~mL}$ of a solution containing $10 \mathrm{mM}$ Tris- $\mathrm{HCl}(\mathrm{pH} 8.0), 0.3 \% \mathrm{NaCl}$ and $1 \%$ of a protease inhibitor cocktail (Sigma-Aldrich, St. Louis, MO, USA). The suspension was then sonicated three times with a Branson 250 Sonifier ( $60 \mathrm{~W}$ pulses for $30 \mathrm{~s}, 30 \mathrm{~s}$ intervals in ice). After 1-2 min of centrifugation to eliminate cell debris, supernatants were centrifuged at $17,000 \times g$ for $60 \min$ at $4{ }^{\circ} \mathrm{C}$. The pellets obtained contained total cell membranes.

Outer membrane fractions were obtained as previously described [36,37]. Briefly, the total membrane pellets were resuspended in a solution containing $20 \mathrm{mM}$ Tris- $\mathrm{HCl}(\mathrm{pH} 8.0), 3 \%(w / v)$ sodium lauryl sarcosinate (Sigma-Aldrich, St. Louis, MO, USA) and 1\% protease inhibitor cocktail (Sigma-Aldrich, St. Louis, MO, USA). The suspension was incubated at room temperature for $20 \mathrm{~min}$ to dissolve the inner membrane. Outer membranes were pelleted by $100,000 \times g$ ultracentrifugation for $60 \mathrm{~min}$ at $4{ }^{\circ} \mathrm{C}$ and washed twice with distilled water. Protein concentration was determined using the BCA Assay Kit (Thermo Scientific, Waltham, MS, USA), and samples were kept at $-20{ }^{\circ} \mathrm{C}$ until use.

Iron-regulated OMP (IROMP) profiles were compared for each $V$. ordalii strain between cells grown with or without iron limitation. Each extract $(20 \mu \mathrm{g})$ was mixed with the SDS-PAGE sample buffer, heated at $95{ }^{\circ} \mathrm{C}$ for $5 \mathrm{~min}$, and separated by SDS-PAGE with $7.5 \%(\mathrm{w} / \mathrm{v})$ acrylamide in the resolving gel. Electrophoresis was performed in a Mini-PROTEAN 3 Cell (Bio-Rad, Portland, ME, USA) at $120 \mathrm{~V}$ for $120 \mathrm{~min}$. Protein bands were stained with $0.05 \%$ Coomassie blue R (Sigma-Aldrich, St. Louis, MO, USA) for at least $1 \mathrm{~h}$ and destained for $2 \mathrm{~h}$ in $10 \%$ methanol and $10 \%$ acetic acid. The relative mobility of each protein was determined by comparison with standard protein markers (Precision Plus Protein Standards, Bio-Rad). Digital images were collected using a G:BOX Chemi XT4 Fluorescent and Chemiluminescent Imaging System (Syngene, Frederick, MD, USA) with GeneSys automatic control software and GeneTools analysis software (Syngene, Frederick, MD, USA). Three independent separations, from two different cultures, were performed for each strain and growth condition. Further analyses were done only to protein bands induced or increased in intensity under iron-limited conditions.

\subsection{Protein Identification by Peptide Mass Fingerprinting (PMF)}

Candidate iron-regulated bands from SDS-PAGE gels were identified by PMF, using MALDI-TOF (Matrix-Assisted Laser Desorption/Ionization Time-of-Flight) Mass Spectrometry analysis, as previously described [38]. In brief, protein bands of interest were manually excised and subjected to in-gel digestion with trypsin using the In-Gel DigestZp Kit (Millipore ES, Madrid, Spain), following the manufacturer's protocol, to extract proteins prior to mass spectrometry analysis. Before digestion, the samples were reduced with dithiothreitol and alkylated with iodoacetamide. Proteins were identified by PMF with an Ultraflex III TOF/TOF (Bruker ES, Madrid, Spain). For negative identifications, due to mixed proteins in a single band, a liquid chromatography ion-trap mass-spectrometer system with an amaZon speed ETD (Bruker ES, Madrid, Spain) was used. The SwissProt and NCBInr protein databases were screened with Mascot v2.3 (Matrix Science). The identified peptides were then subjected to a BLASTP analysis using the NCBI (National Center for Biotechnology Information) database, to search for homologues. 


\subsection{Bioinformatics Tools}

The DNA and protein sequences were analyzed using the NCBI databases through the BLAST algorithms. The protein families database (Pfam 31.0) of EMBL-EBI (European Bioinformatics Institute) was used to predict the protein domain organization [39]. The functional promoters were identified using the online database BPROM. The organization of putative domains in biosynthetic proteins were detected using the PKS/NRPS database (http://nrps.igs.umaryland.edu/).

\subsection{Detection of Siderophore Piscibactin}

Piscibactin was detected as previously described [23] with slight modifications as follows: 1 L of cell-free culture broth of strain Vo-LM-18 was concentrated under vacuum $\left(39{ }^{\circ} \mathrm{C}\right)$ until $300 \mathrm{~mL}$. Then, $150 \mathrm{~mL}$ were transferred to a flat-bottom flask provided with a magnetic stir bar and $750 \mu \mathrm{L}$ of a solution of $\mathrm{GaBr}_{3}$ in $\mathrm{H}_{2} \mathrm{O}(12 \mathrm{mg} / \mathrm{mL})$ were added dropwise over 5 min and gently stirred for another $10 \mathrm{~min}$. This solution was stored at $4{ }^{\circ} \mathrm{C}$ during $24 \mathrm{~h}$. An aliquot of the solution containing piscibactin-Ga(III) complex $(75 \mathrm{~mL})$ was submitted to Solid Phase Extraction (SPE) through an OASIS ${ }^{\circledR}$ (Waters, Cerdanyola del Vallès, Spain) cartridge $\left(35 \mathrm{~cm}^{3}, 6 \mathrm{~g}\right)$ using an extraction vacuum manifold (0.2 bar) and eluted with $30 \mathrm{~mL}$ of the following mixtures of $\mathrm{H}_{2} \mathrm{O}$ and $\mathrm{CH}_{3} \mathrm{CN}: 1: 0 ; 1: 3 ; 1: 1 ; 0: 1$. Fractions were dried out under reduced pressure and subjected to LC-HRMS analysis using an Atlantis dC18 $(100 \mathrm{~mm} \times 4.6 \mathrm{~mm}, 5 \mu \mathrm{m})$ column (Waters) at a flow rate of $1 \mathrm{~mL} / \mathrm{min}$. Separation, with a sample injection volume of $20 \mu \mathrm{L}$, was achieved by a 35 min gradient from $10 \%$ to $100 \%$ of $\mathrm{CH}_{3} \mathrm{CN}_{\text {in }} \mathrm{H}_{2} \mathrm{O}$, then a $5 \mathrm{~min}$ isocratic step of $100 \% \mathrm{CH}_{3} \mathrm{CN}$. LC-ESI(+)-HRMS analysis of the fraction eluted with the mixture $\mathrm{H}_{2} \mathrm{O} / \mathrm{CH}_{3} \mathrm{CN}$ 1:1, named as L3, showed a peak at 12.06 min that displayed the characteristic isotopic cluster of piscibactin-Ga(III) complex at $m / z$ 518.9928/521.9913.

Results are reported following the identification requirements for MS techniques SANTE/11945/2015. Since it was possible detect both ions at significant intensity, the difference between the calculated and the detected exact mass of piscibactin-Ga(III) complex in ppm $(\Delta m / z)$ and the isotopic ratio abundance error ( $\delta$ RIA) of $M+1 / M$ could be obtained using the Formulas (1) and (2). The quality of the spectral information was achieved by narrowing the detection $\mathrm{m} / \mathrm{z}$ range around the compound of interest of 350-600 dalton measured in a LTQ-Orbitrap, which is in agreement with the small values $\delta$ RIA found.

Formula (1)_SI: Mass accuracy:

$$
\Delta \frac{m}{z}=\left|\frac{m \text { measured }-m \text { theoretical }}{m \text { theoretical }} \times 10^{6} \mathrm{ppm}\right| .
$$

Formula (2)—SI: Isotopic ion abundance ratio error $(\delta R I A)$ :

$$
\delta R I A(\%)=\left|100 \times \frac{R I A_{\text {exp }}-R I A_{\text {theo }}}{R I A_{\text {theo }}}\right| .
$$

Presence of the siderophore vanchrobactin in the same cell-free culture supernatants was also detected using the methodology previously described $[19,29]$.

\subsection{Statistical Analysis}

Data from all assays were statistically analyzed using analysis of variance (ANOVA). Significant differences were established as $p<0.05$.

\section{Results}

\subsection{Characterization of the V. ordalii Gene Cluster Encoding a Piscibactin-Like Siderophore}

An in silico analysis of the genome of $V$. ordalii ATCC 33509 shows the presence of a gene cluster homologous to the piscibactin cluster (irpang) described in the chromosome II of V.anguillarum RV22 [29]. 
Both clusters show a high degree of synteny and a similarity between $96 \%$ and $98 \%$ at the amino acid level (Figure 1). This genomic island includes the 11 genes (irp genes) previously identified as part of the plasmid encoding piscibactin in P. damselae subsp. piscicida [27] (Figure 1). An in silico search in GenBank, and previously published works [28], show the presence of homologous gene clusters in several members of the Vibrionaceae family, such as V. cholerae, V. mimicus, V. coralliilyticus, $V$. anguillarum or Photobacterium profundum. It is noteworthy that this gene cluster exhibits about a $40 \%$ similarity with the genes of the HPI pathogenicity island (encoding the synthesis of the siderophore yersiniabactin) of Yersinia spp. and it was reported as a key virulence factor for P. damselae subsp. piscicida $[27,40]$.

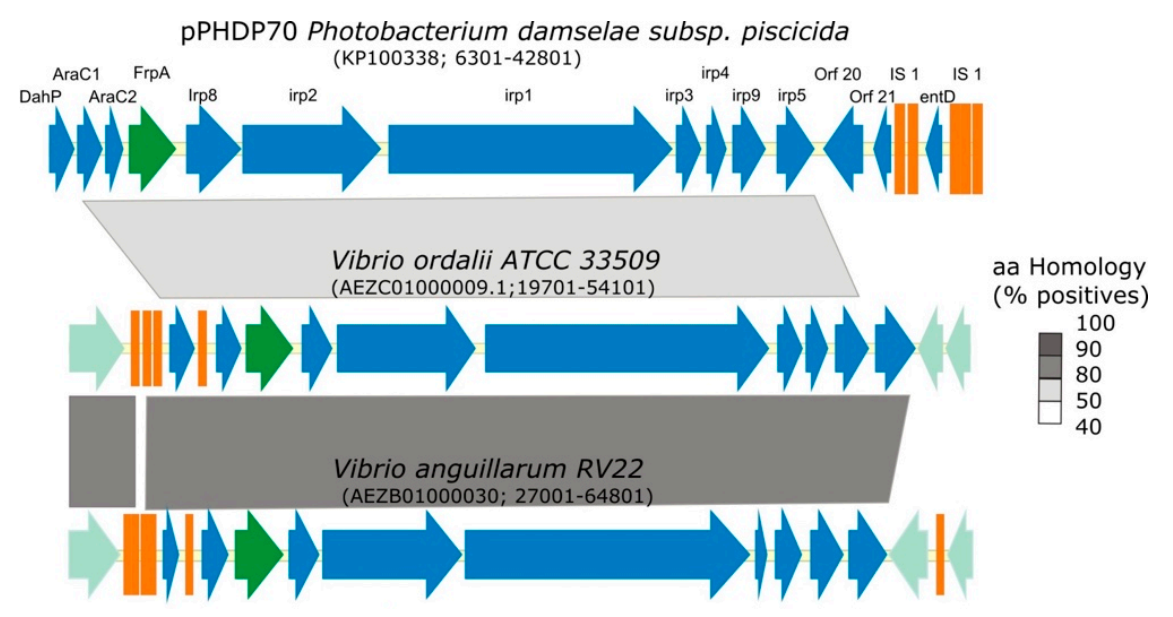

Figure 1. Comparative analysis of the Vibrio ordalii ATCC $33509^{\mathrm{T}}$ irp gene cluster with the homologous chromosomal region of $V$. anguillarum RV22 and with the homologous sequence from plasmid pPHDP70 from $P$. damselae subsp. piscicida. Biosynthetic and regulatory genes are depicted in blue and the gene encoding the outer membrane receptor (FrpA) in green. Other genes and short ORFs are shown in clear green and orange colors. Grey blocks indicate percentages of similarity in the proteins sequence. The GenBank accession numbers and the nucleotide positions interval are indicated below the name of each species.

Piscibactin is synthetized by NRPS-type (non-ribosomal peptide synthetases) enzymes encoded by irp1 and irp 2 genes [23]. The bioinformatic analysis of the resulting proteins Irp1 and Irp2 of V. ordalii showed that the catalytic domains present in these enzymes are almost identical, with a similarity in the amino acid sequence of $99 \%$, to their counterparts encoded by irpang cluster of V. anguillarum RV22 [29] (Figure 2). Thus, the resulting siderophore encoded by the irp cluster of V. ordalii should be also piscibactin.

Like in $V$. anguillarum, the irp cluster genes of $V$. ordalii encode most functions needed for piscibactin synthesis and utilization, although an entD homologue is absent in this gene cluster when compared to the P. damselae subsp. piscicida irp cluster (Figure 1). The entD gene encodes a 4'-phosphopantetheinyl transferase that is required to activate the peptide synthesis domains of non-ribosomal peptide synthetases (NRPS) [41] and it is essential for piscibactin biosynthesis [23]. However, a homologue of this gene is present in the genome of $V$. ordalii as part of the vab gene cluster, encoding the siderophore vanchrobactin $[4,26]$. This entD homologue could provide in trans the function of a 4'-phosphopantetheinyl transferase necessary for piscibactin biosynthesis in $V$. ordalii. We have previously shown that although vanchrobactin could be synthetized by $V$. ordalii, it cannot be used as siderophore since the $\mathrm{ABC}$ transporters necessary for ferric vanchrobactin internalization are not present in the genome of $V$. ordalii [26]. 


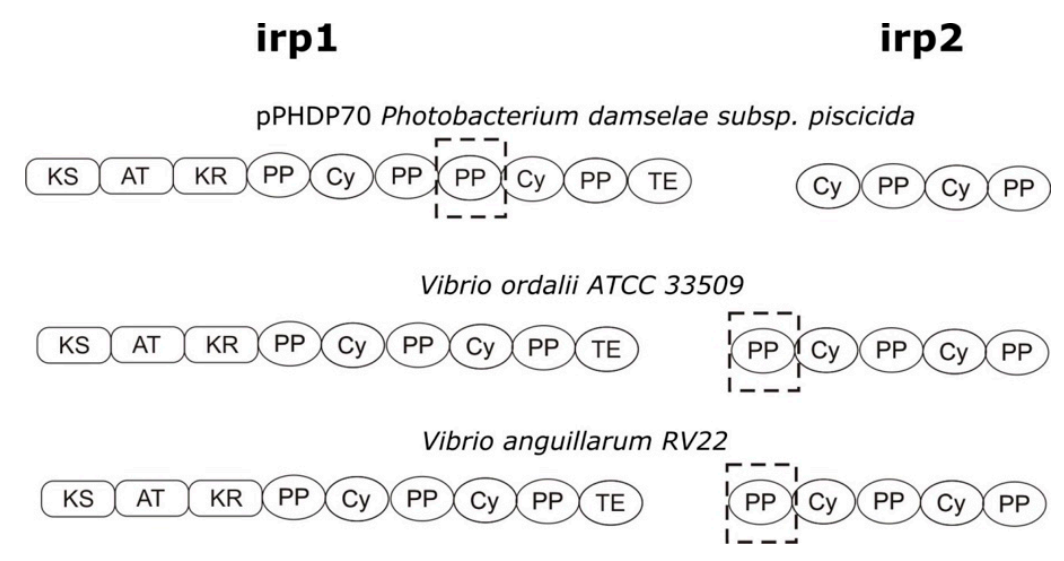

Figure 2. Representation of the catalytic domains predicted in Irp1 and Irp2 enzymes of Photobacterium damselae subsp. piscicida, V. ordalii ATCC $33509^{\mathrm{T}}$ and V. anguillarum RV22. Analysis of domains was performed using the PKS/NRPS database (http://nrps.igs.umaryland.edu/). Abbreviations: AT, acyltransferase; Cy, cyclization; KS, ketoacil synthase; KR, ketoreductase; PP, peptidyl-carrier protein; TE, thioesterase. Dotted boxes highlight the main differences.

\subsection{Transcriptional Analysis and Iron Regulation of the Irp Gene Cluster of V. ordalii}

To test if irp genes of $V$. ordalii were expressed, several RT-PCR (reverse-transcriptase PCR) reactions were performed. The results showed that the irp gene cluster is transcribed as a polycistronic mRNA that includes $\operatorname{araC} 1, \operatorname{araC} 2, \operatorname{frp} A, \operatorname{irp} 1-5, \operatorname{irp} 8$ and irp9 genes (Figure 3). Therefore, all genes putatively encoding the synthesis, regulation and transport of piscibactin could be co-transcribed from the promoter P2 located upstream of araC1 (Figure 3a). An identical result was found for the piscibatin irpang cluster described in V. anguillarum RV22 [29]. This promoter contains a putative Fur box that would indicate that its activity is regulated by the transcriptional regulator Fur in an iron-dependent fashion [33]. An additional promoter P1, also containing a putative Fur box, was located upstream of frpA (Figure 3a). The frpA gene would encode the presumptive ferri-piscibactin outer membrane receptor while araC1 would encode a putative AraC-type transcriptional regulator. Thereby, even though irp genes can be transcribed mainly from the promoter upstream of $\operatorname{araCl}$, the existence of additional active promoters cannot be ruled out.

In order to analyze the expression levels of the irp putative promoters P1 and P2, DNA fragments of ca. 700 nucleotides upstream of frpA and $\operatorname{araC1}$ genes (Figure 3a) were cloned into the plasmid pHRP309 upstream of a promoterless lac $Z$ gene. Resulting plasmids were mobilized into $V$. ordalii Vo-LM-18 and the transcription levels of lac $Z$ were measured by determining $\beta$-galactosidase activity under different conditions of iron availability (Figure 4). The use of the PfrpA (P1) and ParaC1 (P2) presumptive promoters produced significant $\beta$-galactosidase activity when cells were cultured under a strong iron limitation (CM9 medium plus 2,2'-dipyridyl $80 \mu \mathrm{M}$ ). Under iron excess conditions (CM9 or $\mathrm{CM} 9$ plus $\mathrm{FeCl}_{3} 25 \mu \mathrm{M}$ ) the $\beta$-galactosidase activity of the $\mathrm{P} 2$ promoter was $75 \%$ of the $\mathrm{P} 1$ promoter (Figure 4), suggesting a higher basal activity for this promoter. However, under strong iron limitation, the $\mathrm{P} 2$ promoter seems to be $10 \%$ more active than P1, suggesting a tighter control by iron levels. These results demonstrate that the two promoter sequences could serve as transcriptional starts of the whole irp operon, and that both of them are strongly regulated by iron levels with slight variations between them. 
Vibrio ordalii ATCC 33509 (AEZC01000009.1;19701-54101)

(a)

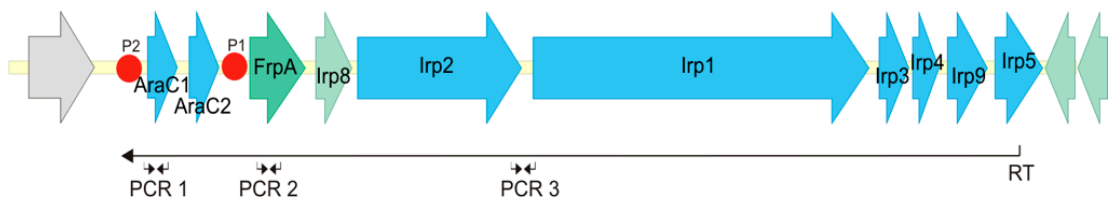

(b)

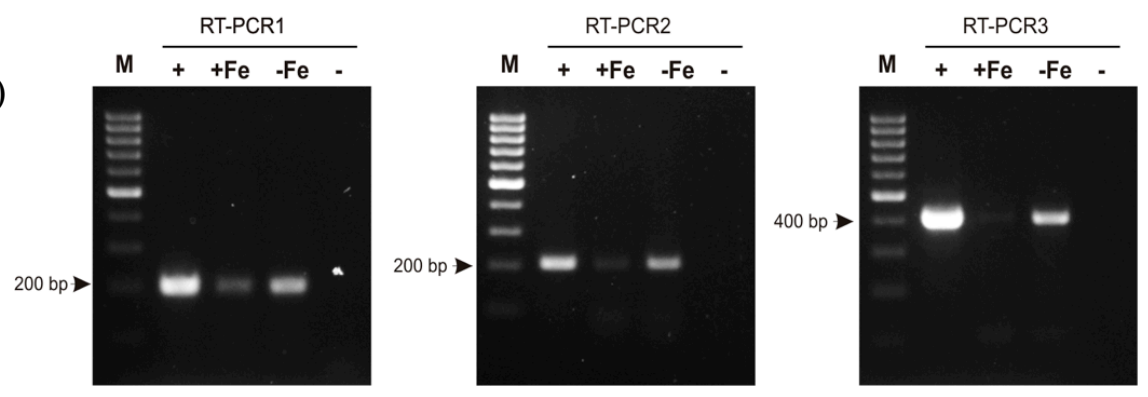

Figure 3. Transcriptional organization of the gene cluster putatively encoding biosynthesis and transport of siderophore piscibactin in $V$. ordalii. (a) The predicted gene functions are: biosynthesis, genes irp1, irp2, irp3, irp4, irp5 and irp9; outer membrane receptor, frpA; transcriptional regulators, ara $\mathrm{C} 1$ and $\operatorname{araC} 2$; and inner membrane exporter of putative siderophore, irp8. Predicted promoters P1 and P2 containing Fur boxes are indicated by red dots. RT denotes the location of primer used in retrotranscriptase reaction while PCR 1, PCR 2 and PCR 3 indicate location of primers for detection of cDNA from piscibactin gene cluster. (b) results of three RT-PCR reactions designed to analyze the transcription of the irp gene cluster. Primer marked as RT, targeted to the $3^{\prime}$-end of irp5 gene, was used to obtain a cDNA that spanned from irp5 to araC1. This cDNA was then used as template for three PCR reactions targeted within araC1 (RT-PCR1), frpA (RT-PCR2) and between irp2 3'-end and irp1 5'-end (RT-PCR3). M, size marker from 100 to $1000 \mathrm{bp}$. Negative controls (-) are RT-PCR reactions lacking reverse transcriptase. Positive controls (+) are PCR reactions using chromosomal DNA as template, +Fe: RT-PCR performed with cells grown under iron excess (TSB-1 $+\mathrm{FeCl}_{3} 20 \mu \mathrm{M}$ ); -Fe: RT-PCR performed with cells grown under iron limitation (TSB-1 +2,2'-dipyridyl $60 \mu \mathrm{M}$ ).

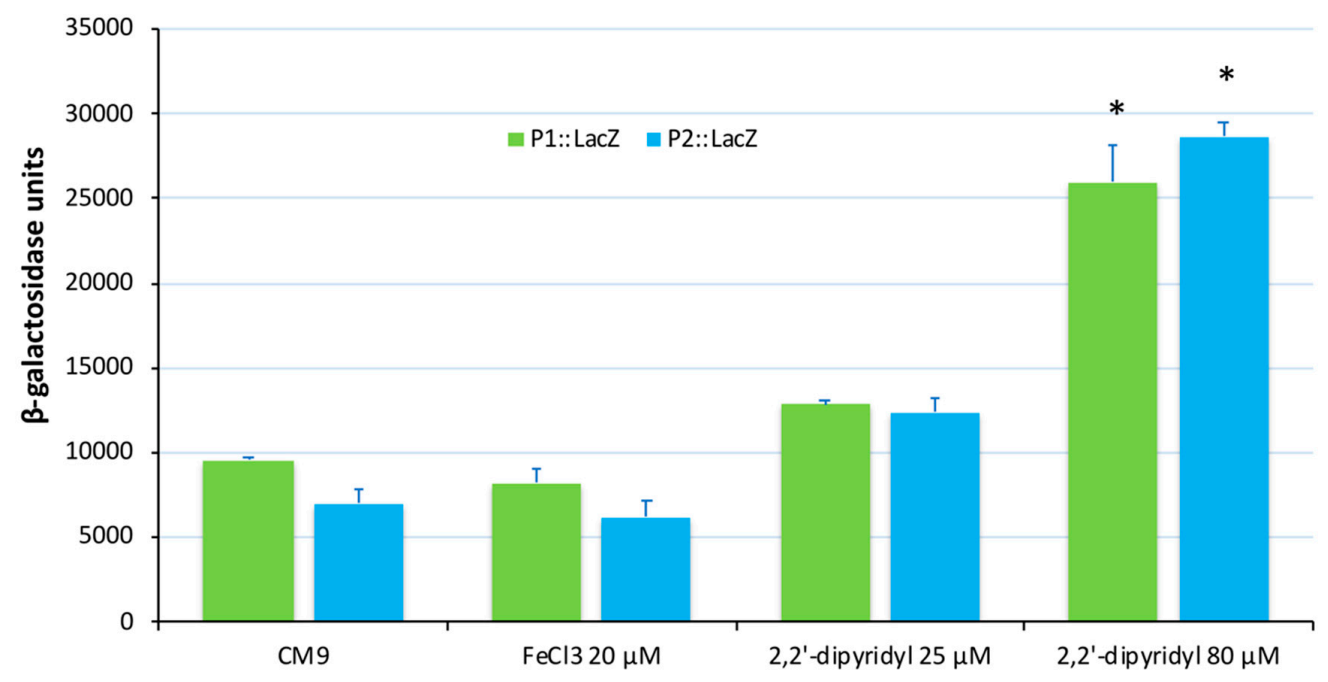

Figure 4. Transcriptional activity ( $\beta$-galactosidase units) of lac $Z$ fusions to $P 1$ and $P 2$ potential promoters of $V$. ordalii. $\beta$-galactosidase activities for promoter $\mathrm{P} 1::$ lac $Z$ and promoter $\mathrm{P} 2:$ : lac $Z$ were measured in cells cultured in CM9 minimal medium, CM9 supplemented with $20 \mu \mathrm{M} \mathrm{FeCl}_{3}$, as an iron excess condition, and in two iron-limiting conditions: CM9 with 2,2'-dipyridyl $25 \mu \mathrm{M}$ and CM9 with 2,2'-dipyridyl $80 \mu \mathrm{M}$. Three independent experiments were performed in triplicate. Bars represent average values with standard deviations indicated by error bars. The data were analyzed using ANOVA significance test $\left({ }^{*} p<0.05\right)$. 


\subsection{Analysis of Iron-Regulated Outer Membrane Proteins}

In Gram-negative bacteria some of the outer membrane proteins (OMP) are involved in iron uptake mechanisms, and most of them are regulated by iron. Thus, in order to detect the expression of OMPs involved in siderophore synthesis and transport in $V$. ordalii we investigated by SDS-PAGE the changes in the OMP profiles when cells were cultured under iron excess or under iron limitation. Some of these proteins could then be identified by PMF. As shown in Figure 5, clear changes in the OMP profile could be detected in three representative strains of $V$. ordalii when cells were cultured under iron deprivation (the strains were cultured in TSB-1 plus half the MIC of the iron chelator 2,2'-dipyridyl). Five main bands (Table 2) could be identified as proteins clearly regulated by iron since all them were present only in membrane fractions of cells grown under iron-limiting conditions. Three of these proteins were high-molecular weight proteins that were unequivocally identified by PMF as VabF (311 kDa band marked as I in Figure 5), Irp1 (270 kDa band marked as II in Figure 5) and Irp2 (224 kDa band marked as III in Figure 5). These three proteins correspond to NRPS enzymes involved in vanchrobactin (VabF) and piscibactin (Irp1 and Irp2) siderophore synthesis. Although NRPSs are cytosolic enzymes, it has been reported that some of them can form membrane-bound multi-enzymatic complexes, called siderosomes, on the inner leaflet of the cytoplasmic membrane [42,43], which could explain their detection in $V$. ordalii membrane fractions. Protein I showed $98 \%$ identity to VabF, a NRPS of $V$. anguillarum involved in vanchrobactin biosynthesis. Proteins II and III clearly correspond with Irp1 and Irp2, the two NRPS involved in the synthesis of piscibactin in P. damselae subsp. piscicida [23,27] (with similarities of $70 \%$ and $68 \%$, respectively) and in V. anguillarum [29] (both proteins with similarities of $98 \%$ ).

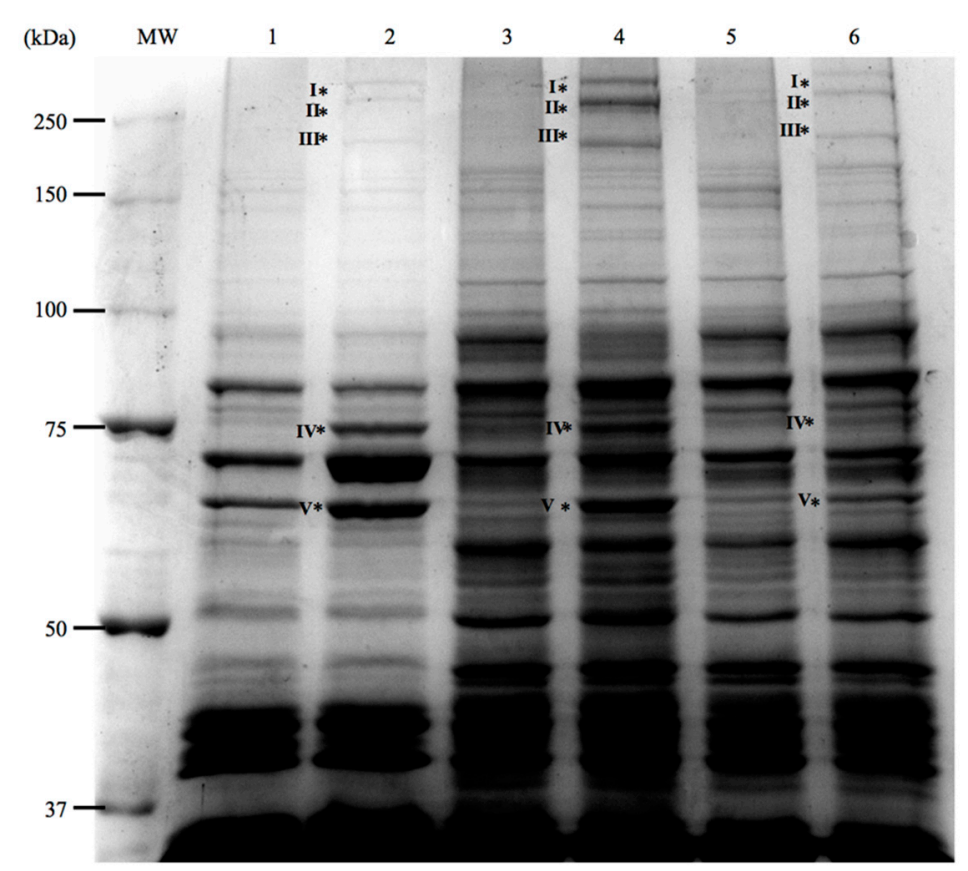

Figure 5. Representative SDS-PAGE gel showing outer membrane protein (OMP) profiles of $V$. ordalii strains under iron-rich and iron-limited conditions. MW: Molecular weight marker; 1 : ATCC $33509^{\mathrm{T}}$ under iron-excess conditions; 2: ATCC $33509^{\mathrm{T}}$ under iron-limitation (TSB-1 + 2,2' -dipyridyl $45 \mu \mathrm{M})$; 3: Vo-LM-13 under iron-excess, 4: Vo-LM-13 under iron-limitation (TSB-1 + 2,2'-dipyridyl $90 \mu \mathrm{M})$; 5: Vo-LM-18 under iron-excess; and 6: Vo-LM-18 under iron-limitation (TSB-1 + 2,2'-dipyridyl $60 \mu \mathrm{M}) .{ }^{*}$ : Proteins expressed only under iron limitation and identified by PMF as follows: I, VabF (vanchrobactin synthesis); II, Irp1; III, Irp2 (piscibactin synthesis); IV, HuvS (heme receptor); V, FrpA (piscibactin receptor). 
Table 2. Identification by peptide mass fingerprinting (PMF) of five proteins differentially expressed under iron limitation in SDS-PAGE gel showed in Figure 5.

\begin{tabular}{ccccc}
\hline $\begin{array}{c}\text { Band in Gel } \\
\text { (Figure 5) }\end{array}$ & $\begin{array}{c}\text { Estimated Size } \\
(\mathbf{k D a})\end{array}$ & Closest Homologues & Accession No. & Similarity (\%) \\
\hline Band I & 311 & VabF, V. anguillarum & CAJ45639.1 & 98 \\
\hline Band II & 270 & $\begin{array}{c}\text { Irp1, V. anguillarum } \\
\text { Irp1, P. damselae } \\
\text { subsp. piscicida }\end{array}$ & WP_019281879.1 & 98 \\
& 224 & $\begin{array}{c}\text { Irp2, V. anguillarum } \\
\text { Irp2, P. damselae } \\
\text { subsp. piscicida }\end{array}$ & WP_019281878.1 & 98 \\
Band III & 79 & AKQ52531.1 & 68 \\
\hline Band IV & 71 & $\begin{array}{c}\text { FrpA, V. anguillarum } \\
\text { FrpA, P. damselae } \\
\text { subsp. piscicida }\end{array}$ & CAJ14788.1 & 99 \\
\hline Band V & & WP_019281876.1 & 96 \\
& & AKQ52529.1 & 68 \\
\hline
\end{tabular}

The other two differentially expressed bands with sizes of 79 kDa (band IV in Figure 5) and 71 $\mathrm{kDa}$ (band V in Figure 5) could be identified as the heme receptor HuvS, showing a 99\% similarity to the homologous protein previously reported in V. anguillarum [44], and the piscibactin receptor FrpA, respectively. The later shows a $68 \%$ similarity with FrpA protein encoded by the plasmidic irp cluster of $P$. damselae subsp piscicida [27,40], and a 96\% similarity with the FrpA protein reported in V. anguillarum [29].

From the analysis of the iron regulated OMP we could conclude that the irp gene cluster of $V$. ordalii must be fully functional, since biosynthetic and siderophore transport proteins are detected in cells grown under low iron conditions.

\subsection{Identification of Siderophores in Cultures of V. ordalii}

The genetic and bioinformatic analyses of the irp operon present in V. ordalii, as well as the identification of biosynthetic enzymes encoded by this cluster and induced under iron limitation, strongly indicate that $V$. ordalii would synthetize the siderophore piscibactin. In order to confirm the synthesis of this siderophore by $V$. ordalii, cell-free culture supernatants of strain Vo-LM-18 grown under iron-restricted conditions were examined for the presence of piscibactin as described in Material and Methods. The presence of the piscibactin-Ga(III) complex was confirmed on the basis of the accurate mass measurements and the characteristic isotopic cluster of the gallium complex (Figure 6). The $\Delta m / z$ results for monoisotopic and isotopic ions $(\mathrm{M}+1)$ were below a tolerance acceptable value of $5 \mathrm{ppm}$ and the $\delta$ RIA values were within the expected value for positive ion mode $(16 \%)$ for a compound with a molecular mass range of 350-600 dalton measured in a LTQ-Orbitrap (Table 3) [45]. From these results, we can unequivocally conclude that piscibactin was present in the culture supernatants of V. ordalii Vo-LM-18.

Additionally, vanchrobactin was also detected in the cultures of strain Vo-LM-18 under iron restriction (data not shown). Solid Phase Extraction (SPE) using HLB cartridges of the cell-free culture supernatants of this strain followed by LC-MS analysis showed a peak with a retention time of $4.68 \mathrm{~min}$, which displays a $[\mathrm{M}+\mathrm{H}]^{+}$ion at $m / z 398.1676$ (calculated for $\mathrm{C}_{16} \mathrm{H}_{24} \mathrm{~N}_{5} \mathrm{O}_{7}, m / z$ 398.1670) in its HRESIMS that corresponds to vanchrobactin $[19,29]$. 


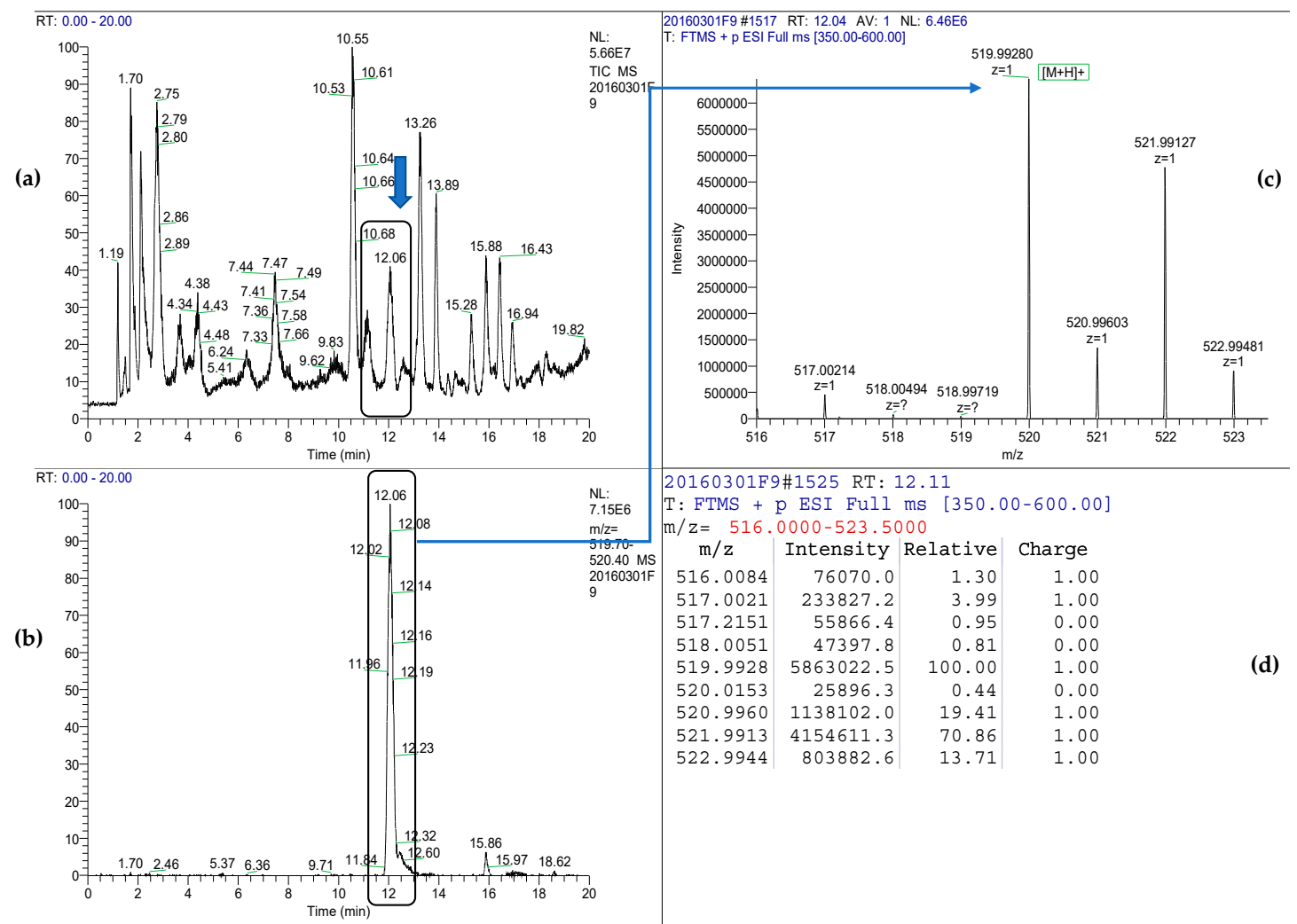

Figure 6. (a) LC-HRMS total ion chromatogram of the fraction containing piscibactin-Ga(III) complex eluted with $\mathrm{H}_{2} \mathrm{O}$ and $\mathrm{CH}_{3} \mathrm{CN}$ (1:1) from an OASIS ${ }^{\circledR}$ HLB cartridge; (b) extracted ion chromatogram from $m / z 519.7-520.4$; (c) high resolution mass spectrum corresponding to the peak with $t_{\mathrm{R}}=12.06$ $\mathrm{min}$; (d) isotopic ion abundance from $\mathrm{m} / \mathrm{z} 516.0-523.5$, including $\mathrm{M}+1 / \mathrm{M}\left({ }^{13} \mathrm{C}_{1} /{ }^{12} \mathrm{C}\right)$, calculated with Thermo Xcalibur software 3.0. LTQ-Orbitrap was operating at a resolving power of 30,000 (m/ $\Delta \mathrm{m})$ with a detection window setting around the compound of interest (between 350 and 600 dalton).

Table 3. List of ions observed in fraction eluted with $\mathrm{H}_{2} \mathrm{O}$ and $\mathrm{CH}_{3} \mathrm{CN}(1: 1)^{\text {a }}$, using LC-ESI-LTQ-Orbitrap in Positive-ion Mode ${ }^{b}$.

\begin{tabular}{|c|c|c|c|c|c|c|}
\hline Ion & $\begin{array}{c}\text { Retention } \\
\text { Time (min) }\end{array}$ & $\begin{array}{l}\text { Detected } \\
{[\mathrm{M}+\mathrm{H}]^{+}}\end{array}$ & $\Delta \mathrm{m} / \mathrm{z}(\mathrm{ppm})$ & Ion Formula & $\begin{array}{c}\text { Mean } \\
\text { Intensity }\end{array}$ & $\delta$ RIA (\%) \\
\hline \multirow{4}{*}{ Piscibactin-Ga(III) } & \multirow{4}{*}{12.08} & 519.99280 & 3.1 & ${ }^{12} \mathrm{C}_{19} \mathrm{H}_{21}{ }^{69} \mathrm{GaN}_{3} \mathrm{O}_{4} \mathrm{~S}_{3}{ }^{+}$ & $5.8 \times 10^{6}$ & - \\
\hline & & 520.99603 & 3.4 & ${ }^{13} \mathrm{C}_{1}{ }^{12} \mathrm{C}_{18} \mathrm{H}_{21}{ }^{69} \mathrm{GaN}_{3} \mathrm{O}_{4} \mathrm{~S}_{3}{ }^{+}$ & $1.1 \times 10^{6}$ & -5.3 \\
\hline & & 521.99127 & 4.4 & ${ }^{12} \mathrm{C}_{19} \mathrm{H}_{21}{ }^{71} \mathrm{GaN}_{3} \mathrm{O}_{4} \mathrm{~S}_{3}{ }^{+}$ & $4.6 \times 10^{6}$ & - \\
\hline & & 522.99481 & 4.1 & ${ }^{13} \mathrm{C}_{1}{ }^{12} \mathrm{C}_{18} \mathrm{H}_{21}{ }^{71} \mathrm{GaN}_{3} \mathrm{O}_{4} \mathrm{~S}_{3}{ }^{+}$ & $8.0 \times 10^{5}$ & 5.9 \\
\hline
\end{tabular}

a Fraction mass $16.9 \mathrm{mg}$. ${ }^{\mathrm{b}}$ Fraction L3 was mixed with $3 \mu \mathrm{L}$ of a $12 \mathrm{mg} / \mathrm{mL}$ solution of $\mathrm{GaBr}_{3} / \mathrm{H}_{2} \mathrm{O}$ just before injection.

\section{Discussion}

$V$. ordalii is the causative agent of vibriosis in several salmonid fish species farmed in several geographic areas around the world [1]. Although it was formerly classified as V. anguillarum biovar II, it was later recognized as a new Vibrio species [46]. Despite the similarities between both species, each of them causes quite different types of vibriosis $[1,47]$ and some important genomic differences were reported between both species, for example the size of the genome of $V$. ordalii being $70 \%$ of that of $V$. anguillarum [4]. Both species also present important phenotypic differences [1]. Thus, the differences could also reach the virulence mechanisms used by each one to cause disease in fish. Among the variety of virulence factors present in $V$. anguillarum, the iron uptake systems are among the best studied [1,48]. However, these mechanisms are yet poorly known in V. ordalii. In a previous work we could detect the production of siderophores and suggested that piscibactin could be a siderophore 
being produced by this bacterium [26]. In the present research we could demonstrate that piscibactin is really the siderophore synthesized by $V$. ordalii under iron deprivation.

Vanchrobactin is a chromosomally encoded siderophore that is conserved among all V. anguillarum isolates as either environmental or pathogenic [21,49]. As noted above, all the genes necessary for vanchrobactin synthesis are also present in the genome of $V$. ordalii [4] and VabF, the NRPS that ensembles vanchrobactin, can be actually detected under low iron conditions (Figure 5). Moreover, we could detect the presence of vanchrobactin in the supernatants of $V$. ordalii cultured under iron limitation (data not shown). However, part of the required transporters, specifically the $A B C$ transporters fot $B-f v t E$, seem to be missed from the genome of $V$. ordalii [4]. Furthermore, although fot $A$, the gene encoding the vanchrobactin outer membrane receptor of $V$. anguillarum [49], is present in the genome of $V$. ordalii, we could never detect any homolog to FvtA in the $V$. ordalii OMP profiles, suggesting that fot $A$ is not expressed. Thus, although $V$. ordalii also produces vanchrobactin, our results suggest that this bacterium is unable to use it as siderophore, confirming previously reported genomic and biological studies $[4,26]$.

In addition to vanchrobactin, some strains of $V$. anguillarum lacking pJM1-type plasmids (that encode the synthesis of anguibactin [50]) produce also piscibactin as siderophore. The synthesis of piscibactin in $V$. anguillarum is favored at low temperatures since the transcriptional activity of the biosynthetic genes is three-times higher at $18{ }^{\circ} \mathrm{C}$ than at $25^{\circ} \mathrm{C}$ [29]. Although in V. anguillarum vanchrobactin and piscibactin are simultaneously produced, the latter is a key virulence factor to infect fish whereas vanchrobactin seems to have a secondary role in virulence. This is in agreement with the observation that piscibactin seems to be the only siderophore used for iron uptake by $V$. ordalii. The fact that piscibactin synthesis in $V$. anguillarum is preferentially expressed below $18{ }^{\circ} \mathrm{C}$ also agrees with the usually lower optimal growth temperature of $V$. ordalii compared to $V$. anguillarum $[2,46,51]$. Thus, synthesis of piscibactin could be an adaptation to infect hosts that grow at low temperatures, and in these conditions piscibactin could be an efficient siderophore. It is noteworthy that piscibactin is the siderophore present in more species within the Vibrionaceae family than any other siderophore system. This wide distribution of piscibactin could be explained by a horizontal gene transfer (HGT) event that was followed by the action of diverse evolutionary forces [28]. As demonstrated in P. damselae subsp. piscicida, piscibactin is encoded by a pathogenicity island which resembles the high pathogenicity island (HPI) encoding the siderophore yersiniabactin in Yersinia [27,40]. The plasmid harboring this pathogenicity island could be transferred to other marine bacteria [27]. Acquisition of piscibactin genes by HGT could lead to the inactivation of other siderophore systems present in the ancient Vibrio genome. A similar event was demonstrated in V. anguillarum, in which the acquisition of the pJM1 plasmid, encoding the anguibactin siderophore system, led to the inactivation of vanchrobactin synthesis by a transposon harbored by the plasmid [21,52]. It is likely that the siderophore with the highest affinity for iron could have a selective advantage.

$V$. ordalii contains a significantly smaller genome than $V$. anguillarum, which explains the physical and ecological differences existing between both species [4]. Besides, this reduced genome suggests that $V$. ordalii may be immersed in the process of evolution toward an endosymbiotic lifestyle [5]. In this scenario, it is likely that vanchrobactin synthesis does not have any advantage, since its production could be more related to persistence into a marine environment than to pathogenesis [21,29]. Since piscibactin is a key virulence factor for $V$. anguillarum strains lacking the anguibactin system, and due to the close genetic relationship between both species, it is reasonable to speculate that the same will be true for $V$. ordalii. Multiple attempts to generate $V$. ordalii knock-out mutants (by the allelic exchange method previously used for $V$. anguillarum [29]) defective in piscibactin production were unsuccessful (data not shown). Further research is needed to try to generate piscibactin-deficient mutants in this bacterium to clearly demonstrate the involvement of piscibactin in the pathogenesis of vibriosis caused by $V$. ordalii.

In conclusion, $V$. ordalii produces piscibactin and vanchrobactin as siderophores when it is cultured under low iron conditions, but only piscibactin is used for iron uptake. The fact that piscibactin is a key 
virulence factor in other fish pathogens like P. damselae subsp. piscicida and V. anguillarum, highlights the importance of this siderophore in the pathogenesis of diseases caused by Vibrionaceae members in poikilothermic animals.

Author Contributions: Conceptualization, M.B., J.R., C.J., R.A.-H. and M.L.L.; data curation, M.B. and J.C.F.-M.; funding acquisition, J.R., C.J., R.A.-H. and M.L.L.; investigation, P.R., M.B. and J.C.F.-M.; methodology, P.R., M.B. and J.C.F.-M.; project administration, A.E.T.; supervision, A.E.T., J.R., C.J., R.A.-H. and M.L.L.; validation, A.E.T.; visualization, P.R., M.B., J.C.F.-M. and J.R.; writing—original draft, P.R., R.A.-H. and M.L.L.; writing—review and editing, C.J., R.A.-H. and M.L.L.

Funding: This work was supported by Grants CONICYT/FONDAP/15110027 and FONDECYT No 1190283 from the Comisión Nacional de Investigación Científica y Tecnológica (CONICYT, Chile), and by grants AGL2015-63740-C2-1-R and AGL2015-63740-C2-2-R from the State Agency for Research (AEI) of Spain, both co-funded by the FEDER Programme from the European Union. Grants from Xunta de Galicia (Spain) supporting work at University of Santiago de Compostela (grant GRC2018/18) and University of A Coruña (grant GRC2018/39 and CICA-INIBIC support ED431E2018/03) are also acknowledged.

Acknowledgments: Pamela Ruiz acknowledges reception of a CONICYT Doctoral Scholarship (No. 21110146). Ruben Avendaño-Herrera acknowledges Rodolfo Paredes (from Universidad Andrés Bello, Chile) for his help in protein analysis.

Conflicts of Interest: The authors declare no conflict of interest. The funders had no role in the design of the study; in the collection, analyses, or interpretation of data; in the writing of the manuscript, or in the decision to publish the results.

\section{References}

1. Toranzo, A.E.; Magariños, B.; Avendaño-Herrera, R. Vibriosis: Vibrio anguillarum, V. ordalii and Aliivibrio salmonicida. In Fish Viruses and Bacteria: Pathobiology and Protection; Woo, P.T.K., Cipriano, R.C., Eds.; CABI: London, UK, 2017; pp. 314-333.

2. Colquhoun, D.J.; Aase, I.L.; Wallace, C.; Baklien, A.; Gravningen, K. First description of Vibrio ordalii from Chile. Bull. Eur. Assoc. Fish. Pathol. 2004, 24, 185-188.

3. Ruiz, P.; Poblete, M.; Yañez, A.J.; Irgang, R.; Toranzo, A.E.; Avendaño-Herrera, R. Cell-surface properties of Vibrio ordalii strains isolated from Atlantic salmon Salmo salar in Chilean farms. Dis. Aquat. Organ. 2015, 113, 9-23. [CrossRef] [PubMed]

4. Naka, H.; Dias, G.M.; Thompson, C.C.; Dubay, C.; Thompson, F.L.; Crosa, J.H. Complete genome sequence of the marine fish pathogen Vibrio anguillarum harboring the pJM1 virulence plasmid and genomic comparison with other virulent strains of V. anguillarum and V. ordalii. Infect. Immun. 2011, 79, 2889-2900. [CrossRef] [PubMed]

5. Steinum, T.M.; Karatas, S.; Martinussen, N.T.; Meirelles, P.M.; Thompson, F.L.; Colquhoun, D.J. Multilocus Sequence Analysis of Close Relatives Vibrio anguillarum and Vibrio ordalii. Appl. Environ. Microbiol. 2016, 82, 5496-5504. [CrossRef] [PubMed]

6. Ruiz, P.; Poblete-Morales, M.; Irgang, R.; Toranzo, A.E.; Avendaño-Herrera, R. Survival behaviour and virulence of the fish pathogen Vibrio ordalii in seawater microcosms. Dis. Aquat. Organ. 2016, 120, 27-38. [CrossRef] [PubMed]

7. Miethke, M. Molecular strategies of microbial iron assimilation: From high-affinity complexes to cofactor assembly systems. Metallomics 2013, 5, 15-28. [CrossRef] [PubMed]

8. Skaar, E.P.; Raffatellu, M. Metals in infectious diseases and nutritional immunity. Metallomics 2015, 7, 926-928. [CrossRef] [PubMed]

9. Wilson, B.R.; Bogdan, A.R.; Miyazawa, M.; Hashimoto, K.; Tsuji, Y. Siderophores in Iron Metabolism: From Mechanism to Therapy Potential. Trends Mol. Med. 2016, 22, 1077-1090. [CrossRef] [PubMed]

10. Hood, M.I.; Skaar, E.P. Nutritional immunity: Transition metals at the pathogen-host interface. Nat. Rev. Microbiol. 2012, 10, 525-537. [CrossRef]

11. Fillat, M.F. The FUR (ferric uptake regulator) superfamily: Diversity and versatility of key transcriptional regulators. Arch. Biochem. Biophys. 2014, 546, 41-52. [CrossRef]

12. Richard, K.L.; Kelley, B.R.; Johnson, J.G. Heme Uptake and Utilization by Gram-Negative Bacterial Pathogens. Front. Cell. Infect. Microbiol. 2019, 9, 81. [CrossRef] [PubMed] 
13. Holden, V.I.; Bachman, M.A. Diverging roles of bacterial siderophores during infection. Metallomics 2015, 7, 986-995. [CrossRef] [PubMed]

14. Ellermann, M.; Arthur, J.C. Siderophore-mediated iron acquisition and modulation of host-bacterial interactions. Free Radic. Biol. Med. 2017, 105, 68-78. [CrossRef] [PubMed]

15. Stork, M.; Di Lorenzo, M.; Mouriño, S.; Osorio, C.R.; Lemos, M.L.; Crosa, J.H. Two tonB systems function in iron transport in Vibrio anguillarum, but only one is essential for virulence. Infect. Immun. 2004, 72, 7326-7329. [CrossRef] [PubMed]

16. Kuehl, C.J.; Crosa, J.H. The TonB energy transduction systems in Vibrio species. Future Microbiol. 2010, 5 , 1403-1412. [CrossRef] [PubMed]

17. Krewulak, K.D.; Vogel, H.J. TonB or not TonB: Is that the question? Biochem. Cell Biol. 2011, 89, 87-97. [CrossRef] [PubMed]

18. Avendaño-Herrera, R.; Toranzo, A.E.; Romalde, J.L.; Lemos, M.L.; Magariños, B. Iron uptake mechanisms in the fish pathogen Tenacibaculum maritimum. Appl. Environ. Microbiol. 2005, 71, 6947-6953. [CrossRef] [PubMed]

19. Soengas, R.G.; Anta, C.; Espada, A.; Paz, V.; Ares, I.R.; Balado, M.; Rodríguez, J.; Lemos, M.L.; Jiménez, C. Structural characterization of vanchrobactin, a new catechol siderophore produced by the fish pathogen Vibrio anguillarum serotype O2. Tetrahedron Lett. 2006, 47, 7113-7116. [CrossRef]

20. Lemos, M.L.; Osorio, C.R. Heme, an iron supply for vibrios pathogenic for fish. Biometals 2007, 20, 615-626. [CrossRef]

21. Lemos, M.L.; Balado, M.; Osorio, C.R. Anguibactin- versus vanchrobactin-mediated iron uptake in Vibrio anguillarum: Evolution and ecology of a fish pathogen. Environ. Microbiol. Rep. 2010, 2, 19-26. [CrossRef]

22. Retamales, J.; González-Contreras, A.; Salazar, S.; Toranzo, A.E.; Avendaño-Herrera, R. Iron utilization and siderophore production by Streptococcus phocae isolated from diseased Atlantic salmon (Salmo salar). Aquaculture 2012, 364-365, 305-311. [CrossRef]

23. Souto, A.; Montaos, M.A.; Rivas, A.J.; Balado, M.; Osorio, C.R.; Rodríguez, J.; Lemos, M.L.; Jiménez, C. Structure and Biosynthetic Assembly of Piscibactin, a Siderophore from Photobacterium damselae subsp. piscicida, Predicted from Genome Analysis. Eur. J. Org. Chem. 2012, 2012, 5693-5700.

24. Balado, M.; Souto, A.; Vences, A.; Careaga, V.P.; Valderrama, K.; Segade, Y.; Rodríguez, J.; Osorio, C.R.; Jiménez, C.; Lemos, M.L. Two Catechol Siderophores, Acinetobactin and Amonabactin, Are Simultaneously Produced by Aeromonas salmonicida subsp. salmonicida Sharing Part of the Biosynthetic Pathway. ACS Chem. Biol. 2015, 10, 2850-2860. [PubMed]

25. Bethke, J.; Poblete-Morales, M.; Irgang, R.; Yañez, A.; Avendaño-Herrera, R. Iron acquisition and siderophore production in the fish pathogen Renibacterium salmoninarum. J. Fish. Dis. 2016, 39, 1275-1283. [CrossRef] [PubMed]

26. Ruiz, P.; Balado, M.; Toranzo, A.E.; Poblete-Morales, M.; Lemos, M.L.; Avendaño-Herrera, R. Iron assimilation and siderophore production by Vibrio ordalii strains isolated from diseased Atlantic salmon Salmo salar in Chile. Dis. Aquat. Organ. 2016, 118, 217-226. [CrossRef]

27. Osorio, C.R.; Rivas, A.J.; Balado, M.; Fuentes-Monteverde, J.C.; Rodríguez, J.; Jiménez, C.; Lemos, M.L.; Waldor, M.K. A Transmissible Plasmid-Borne Pathogenicity Island Confers Piscibactin Biosynthesis in the Fish Pathogen Photobacterium damselae subsp. piscicida. Appl. Environ. Microbiol. 2015, 81, 5867-5879. [CrossRef] [PubMed]

28. Thode, S.K.; Rojek, E.; Kozlowski, M.; Ahmad, R.; Haugen, P. Distribution of siderophore gene systems on a Vibrionaceae phylogeny: Database searches, phylogenetic analyses and evolutionary perspectives. PLoS ONE 2018, 13, e0191860. [CrossRef]

29. Balado, M.; Lages, M.A.; Fuentes-Monteverde, J.C.; Martínez-Matamoros, D.; Rodríguez, J.; Jiménez, C.; Lemos, M.L. The Siderophore Piscibactin Is a Relevant Virulence Factor for Vibrio anguillarum Favored at Low Temperatures. Front. Microbiol. 2018, 9, 1766. [CrossRef] [PubMed]

30. Avendaño-Herrera, R.; Maldonado, J.P.; Tapia-Cammas, D.; Feijoo, C.G.; Calleja, F.; Toranzo, A.E. PCR protocol for detection of Vibrio ordalii by amplification of the vohB (hemolysin) gene. Dis. Aquat. Organ. 2014, 107, 223-234. [CrossRef] 
31. Lemos, M.L.; Salinas, P.; Toranzo, A.E.; Barja, J.L.; Crosa, J.H. Chromosome-mediated iron uptake system in pathogenic strains of Vibrio anguillarum. J. Bacteriol. 1988, 170, 1920-1925. [CrossRef]

32. Solovyev, V.; Salamov, A. Automatic Annotation of Microbial Genomes and Metagenomic Sequences. In Metagenomics and Its Applications in Agriculture, Biomedicine and Environmental Studies; Li, R.W., Ed.; Nova Science Publishers: New York, NY, USA, 2011; pp. 61-78.

33. Escolar, L.; Perez-Martin, J.; de Lorenzo, V. Opening the iron box: Transcriptional metalloregulation by the Fur protein. J. Bacteriol. 1999, 181, 6223-6229. [PubMed]

34. Parales, R.E.; Harwood, C.S. Construction and use of a new broad-host-range lacZ transcriptional fusion vector, pHRP309, for Gram- bacteria. Gene 1993, 133, 23-30. [CrossRef]

35. Miller, J.H. Experiments in Molecular Genetics; Cold Spring Harbor Laboratory: Cold Spring Harbor, NY, USA, 1972.

36. Crosa, J.H.; Hodges, L.L. Outer membrane proteins induced under conditions of iron limitation in the marine fish pathogen Vibrio anguillarum 775. Infect. Immun. 1981, 31, 223-227. [PubMed]

37. Toranzo, A.E.; Barja, J.L.; Potter, S.A.; Colwell, R.R.; Hetrick, F.M.; Crosa, J.H. Molecular factors associated with virulence of marine vibrios isolated from striped bass in Chesapeake Bay. Infect. Immun. 1983, 39, 1220-1227. [PubMed]

38. Puentes, B.; Balado, M.; Bermudez-Crespo, J.; Osorio, C.R.; Lemos, M.L. A proteomic analysis of the iron response of Photobacterium damselae subsp. damselae reveals metabolic adaptations to iron levels changes and novel potential virulence factors. Vet. Microbiol. 2017, 201, 257-264.

39. Finn, R.D.; Bateman, A.; Clements, J.; Coggill, P.; Eberhardt, R.Y.; Eddy, S.R.; Heger, A.; Hetherington, K.; Holm, L.; Mistry, J.; et al. Pfam: The protein families database. Nucleic Acids Res. 2014, 42, D222-D230. [CrossRef] [PubMed]

40. Osorio, C.R.; Juiz-Rio, S.; Lemos, M.L. A siderophore biosynthesis gene cluster from the fish pathogen Photobacterium damselae subsp. piscicida is structurally and functionally related to the Yersinia high-pathogenicity island. Microbiology 2006, 152, 3327-3341.

41. Crosa, J.H.; Walsh, C.T. Genetics and assembly line enzymology of siderophore biosynthesis in bacteria. Microbiol. Mol. Biol. Rev. 2002, 66, 223-249. [CrossRef]

42. Imperi, F.; Visca, P. Subcellular localization of the pyoverdine biogenesis machinery of Pseudomonas aeruginosa: A membrane-associated "siderosome". FEBS Lett. 2013, 587, 3387-3391. [CrossRef]

43. Gasser, V.; Guillon, L.; Cunrath, O.; Schalk, I.J. Cellular organization of siderophore biosynthesis in Pseudomonas aeruginosa: Evidence for siderosomes. J. Inorg. Biochem. 2015, 148, 27-34. [CrossRef]

44. Mouriño, S.; Rodríguez-Ares, I.; Osorio, C.R.; Lemos, M.L. Genetic variability of the heme uptake system among different strains of the fish pathogen Vibrio anguillarum: Identification of a new heme receptor. Appl. Environ. Microbiol. 2005, 71, 8434-8441. [CrossRef] [PubMed]

45. Xu, Y.; Heilier, J.F.; Madalinski, G.; Genin, E.; Ezan, E.; Tabet, J.C.; Junot, C. Evaluation of accurate mass and relative isotopic abundance measurements in the LTQ-orbitrap mass spectrometer for further metabolomics database building. Anal. Chem. 2010, 82, 5490-5501. [CrossRef] [PubMed]

46. Schiewe, M.H.; Trust, T.J.; Crosa, J.H. Vibrio ordalii sp. nov.: A causative agent of vibriosis in fish. Curr. Microbiol. 1981, 6, 343-348. [CrossRef]

47. Ransom, D.P.; Lannan, C.N.; Rohovec, J.S.; Fryer, J.L. Comparison of histopathology caused by Vibrio anguillarum and Vibrio ordalii in three species of Pacific salmon. J. Fish. Dis. 1984, 7, 107-115. [CrossRef]

48. Li, Y.; Ma, Q. Iron Acquisition Strategies of Vibrio anguillarum. Front. Cell. Infect. Microbiol. 2017, 7, 342. [CrossRef] [PubMed]

49. Balado, M.; Osorio, C.R.; Lemos, M.L. FvtA is the receptor for the siderophore vanchrobactin in Vibrio anguillarum: Utility as a route of entry for vanchrobactin analogues. Appl. Environ. Microbiol. 2009, 75, 2775-2783. [CrossRef] [PubMed]

50. Stork, M.; Di Lorenzo, M.; Welch, T.J.; Crosa, L.M.; Crosa, J.H. Plasmid-mediated iron uptake and virulence in Vibrio anguillarum. Plasmid 2002, 48, 222-228. [CrossRef] 
51. Actis, L.A.; Tolmasky, M.E.; Crosa, J.H. Vibriosis. In Fish Diseases and Disorders; Woo, P.T.K., Bruno, D.W., Eds.; CAB International: London, UK, 2011; Volume 3, pp. 570-604.

52. Naka, H.; Lopez, C.S.; Crosa, J.H. Reactivation of the vanchrobactin siderophore system of Vibrio anguillarum by removal of a chromosomal insertion sequence originated in plasmid pJM1 encoding the anguibactin siderophore system. Environ. Microbiol. 2008, 10, 265-277. [CrossRef] [PubMed] 